\title{
PENGARUH KUALIFIKASI AKADEMIK DAN PENGALAMAN KERJA PADA KINERJA DOSEN
}

(The Influence of Academic Qualificatin and Working Experience toward The Performance of Lecturers)

\author{
Muh. Chotim*
}

\begin{abstract}
Abstrak
Penelitian ini bertujuan untuk mengetahui pengaruh kualifikasi akademik dan pengalaman kerja pada kinerja dosen IKIP PGRI Madiun. Subyek penelitian adalah seluruh dosen di IKIP PGRI Madiun (155 dosen), dengan jumlah sampel sebanyak 105 dosen yang diambil dengan menggunakan teknik proportional random sampling. Penelitian ini menggunakan jenis pendekatan kuantitatif yang bersifat expost-facto. Data penelitian dianalisis dengan menggunakan teknik multi regression.

Berdasarkan analisis data, diperoleh hasil sebagai berikut: pertama, terdapat pengaruh signifikan kualifikasi akademik dan pengalaman kerja pada kinerja dosen ( $F_{h}$ 9,539 dengan signifikansi $(P)$ 0,00<0,05 dan adjusted $R$ square 0,141). Kedua, terdapat pengaruh yang signifikan kualifikasi akademik pada kinerja dosen ( $t_{h}$ 2,042 dengan signifikansi (P) 0,044 < 0,05 dan standarlized coefficients $0,188)$. Ketiga, terdapat pengaruh yang signifikan pengalaman kerja pada kinerja dosen $\left(t_{h}\right.$ 3,504 dengan signifikansi $(P)$ 0,001 $<0,05$ dan standarlized coefficients $0,322)$.
\end{abstract}

Kata kunci: Kualifikasi Akademik, Pengalaman Kerja, Kinerja Dosen

* Muh. Chotim adalah Dosen Bimbingan dan Konseling IKIP PGRI Madiun 


\section{Pendahuluan}

Dosen mempunyai fungsi, peran dan kedudukan yang sangat penting dan strategis dalam upaya meningkatkan dan menjamin mutu pendidikan, khususnya mutu pendidikan tinggi. Mutu pendidikan tinggi sangat ditentukan oleh dosen dalam memainkan peran dan fungsinya, terutama peran dan fungsinya terkait dengan Tridharma Perguruan Tinggi. Dosen merupakan ujung tombak berada pada garis terdepan dalam menentukan kualitas pelayanan (fron line provider and determine the quality of service delivery system),. Sumardjoko (2010:8) menyebutkan bahwa dosen merupakan salah satu komponen yang sangat menentukan mutu perguruan tinggi, yang dalam setiap aktivitasnya berhubungan dengan banyak hal, yakni masalah pengajaran, penelitian dan pengabdian kepada masyarakat. Karena dosen menjadi ujung tombak yang menentukan kualitas perguruan tinggi yang harus mampu memainkan peran dan fungsinya, maka dosen dituntut untuk memiliki kualifikasi akademik yang sesuai dengan jenis, jenjang dan satuan pendidikan formal di tempat penugasan, relevan dan konsisten dengan bidang tugas dan tanggung jawab yang diembannnya. Di samping kualifikasi akademik, pengalaman kerja dosen juga penting untuk dimiliki, sehingga dosen akan mampu berkinerja dengan baik, mampu memainkan peran dan fungsinya secara profesional.

Namun bagaimana realitasnya terkait dengan kualifikasi akademik, pengalaman kerja dan kinerja dosen IKIP PGRI Madiun? Banyak fenomena yang menarik untuk dikaji, antara lain adanya anggapan, bahwa kinerja dosen kurang memuaskan pimpinan dan mahasiswa. Fenomena ini didukung oleh banyaknya dosen baru yang dianggap belum banyak pengalaman, di samping sebagian dosen kualifikasi akademiknya belum memenuhi standar minimum (magister atau S.2). Berdasarkan fenomena-fenomena tersebut, maka peneliti merasa tertarik untuk melakukan penelitian dengan judul "Pengaruh Kualifikasi Akademik dan Pengalaman Kerja pada Kinerja Dosen IKIP PGRI Madiun”,

Fatah (2003), kinerja diartikan sebagai ungkapan kemajuan yang didasari oleh pengetahuan, keterampilan, dan sikap serta motivasi untuk menghasilkan sesuatu. Riduwan dan Kuncoro (2008:189), kinerja adalah hasil atau tingkat keberhasilan seseorang secara keseluruhan selama periode tertentu dalam 
melaksankan tugas dibandingkan dengan berbagai kemungkinan, seperti standar hasil kerja, target atau sasaran atau kriteria yang telah ditentukan dan disepakati bersama". Robbins, S.P. (2006) menjelaskan bahwa kinerja sebagai fungsi interaksi antara kemampuan atau ability (A), motivasi atau motivation (M) dan kesempatan atau oppurtunity $(\mathrm{O})$, yang dirumuskan menjadi: Kinerja = F $(\mathrm{A} \times \mathrm{M}$ x O). Artinya; kinerja merupakan fungsi dari kemampuan, motivasi dan kesempatan. Denggan demikian, kinerja ditentukan oleh faktor: kemampuan, motivasi dan kesempatan.

Gibson (1992:34) menyebutkan tiga perangkat variabel (faktor) yang mempengaruhi perilaku dan kinerja individu, yaitu: (1) variabel individual, terdiri dari: kemampuan dan ketrampilan (mental dan fisik), latar belakang (keluarga, tingkat sosial, pendidikan, pengalaman), demografis (umur, asal-usul, jenis kelamin); (2) variabel organisasi, terdiri dari: sumber daya, kepemimpinan, imbalan; (3) variabel psikologis, terdiri dari: persepsi, sikap, kepribadian, belajar dan motivasi.

Berdasarkan beberapa pendapat di atas, secara garis besarnya faktor yang mempengaruhi kinerja (dosen) dapat dikelompokkan menjadi tiga, yaitu faktor internal (dosen), eksternal dan faktor organisasi. Faktor-faktor tersebut bisa berdampak positif maupun negative. Jika faktor internal, eksternal dan faktor organisasi tersebut positif, dalam arti mendukung kinerja, maka dapat dipastikan kinerja seseorang (dosen) pasti baik dan memuaskan. Namun sebaliknya, jika faktor kinerja tersebut negatif (jelak), dalam arti tidak mendukung kinerja, maka dapat dipastikan kinerja seseorang (dosen) akan jelek dan tidak memuaskan.

Kinerja dosen disini dapat dimaknai sebagai kemampuan dalam melaksanakan tugas pada bidang pendidikan / pengajaran, pada bidang penelitian dan pengabdian kepada masyarakat. Sumardjoko (2010) ada tiga kriteria penting yang perlu diperhatikan dalam mengukur(menilai) kinerja dosen, yaitu bagaimana perannya dalam pendidikan/ pengajaran, penelitian dan dalam pengabdiannya kepada masyarakat. Peran dosen tolok ukurnya adalah unjuk kerja (kinerja dosen) yang diwujudkan dalam pelayanan, baik yang bersifat kulitatif maupun kuantitatif dalam satuan waktu tertentu. 
Menurut Sumardjoko (2010) kriteria peran dosen dapat dikembangkan secara terperinci berdasarkan bidang tugasnya sebagai berikut:

1). Peran Dosen dalam Pendidikan dan Pengajaran

Dosen mempunyai tugas dan tanggung jawab mengajar, membimbing dan melatih ketrampilan mahasiswanya. Kenneth dalam Sumarjoko (2010:53) menyebutkan ada tiga faktor yang berkaitan dengan tugas dosen dalam melaksnakan pendidikan / pengajaran, yaitu tugas dosen berkaitan dengan mahasiswa, dengan profesi dan dengan institusi.

a). Tugas dosen dalam pendidikan / pengajaran yang berkaitan dengan mahasiswa, meliputi: (1) melaksanakan pengajaran, dengan perencanaanan /persiapan matang, tepat watu, penilaian secara objektif; (2) melaksanakan bimbingan (akademik dan pribadi), (3) memberikan keteladanan akademik, intelektualitas, integritas pribadi, dan etika profesi; (4) tidak menggunakan kedudukan dan pengaruhnya di kelas untuk menyampaikan materi dan masalah di luar lingkup mata kuliah dan kompetensinya.

b). Tugas dosen dalam pengajaran berkaitan dengan profesi, meliputi beberapa tanggung jawab dalam: (1) meningkatkan keefektifan mengajar dengan mencari cara-cara baru, memotivasi dam memperbaiki metode evaluasi prestasi mahasiswa; (3) mengembangkan ilmu pengetahuan bidang studi keahliannya, melalui penelitian, analisis dan penulisan kreatif, diskusi atau seminar; (4) membantu kolega dan lembaga dalam pengembangan kurikulum, kegiatan ilmiah jurusan dan lain sebagainya; (5) melindungi dan meningkatkan gengsi akademik dan profesi dosen; antara lain dengan membantu merekrut dosen baru, memberikan rekomendasi objektif kenaikan jabatan akademik kolega, (6) memberi contoh menghormati hak orang lain untuk berbeda pendapat.

c). Tugas dosen dalam pengajaran berkaitan dengan institusi, meliputi: (1) melaksanakan tugas kelembagaan dengan baik; (2) menggunakan dana yang dipercayakan dengan sebaik-baiknya sesuai anggaran; (3) berusaha mencegah terjadinya kerugian financial atau hal lain yang merugikan lembaga; (4) mencegah terjadinya penggunaan sumber dana/daya untuk keuntungan pribadi; (5) memberi dukungan dengan berpatisipasi aktif di lembaga; (6) memiliki komitmen yang mantap dalam pengembangan perpustakaan, laboratorium; (7) tidak me- 
nyampaikan ide kepada masyarakat mengatasnamakan lembaga, melainkan sebagai cendekiawan.

Kaitannya dengan tugas pendidikan / pengajaran masalah penguasaan materi dan ketrampilan teknis dalam proses belajar mengajar merupakan dua hal yang mutlak harus ada pada dosen. Melalui penguasaan materi mendidik dapat dilaksanakan. Pelaksanaan pengajaran ini menempati kedudukan sentral sebab pada kegiatan ini terjadi titik temu antara pendidik dengan terdidik dalam tugas pelaksanaan misi pendidikan"

Berdasarkan buku II Pedoman Pelaksanaan Sistem Pendidikan Tenaga Kependidikan di Indonesia (Depdiknas 2003:7) profil penampilan mengajar dapat diidentifikasikan dengan penguasaan sepuluh kompetensi: (1) Penguasaan bahan bidang studi dan metodologi; (2) Mengelola progam belajar mengajar, meliputi: merumuskan tujuan, mengenal,memilih dan menggunakan metode mengajar; memilih dan menyusun prosedur intruksional, melaksanakan program belajar mengajar; mengenal kemampuan anak, merencanakan dan melaksanakan pengajaran remedial; (3) Mengelola kelas, meliputi: tata ruang, iklim belajar mengajar; (4) Menggunakan media dan sumber belajarr, meliputi: memilih dan menggunakan media; membuat alat bantu sederhana; menggunakan dan mengelola laboratorium dalam rangka proses belajar mengajar; serta menggunakan micro teaching dalam PPL; (5) Menguasai landasan kependidikan; (6) Mengelola interaksi belajar; (7) Menilai prestasi belajar siswa; (8) Mengenal fungsi dan progam bimbingan dan penyuluhan; (9) Mengenal dan menyelenggarakan administrasi sekolah; dan; (10) Memahami prinip-prinsip dan menafsirkan hasil penelitian pendidikan guna keperluan pengajaran.

Berdasarkan penjelasan kompetensi di atas dapat disarikan, bahwa penguasaan kompetensi meliputi sikap dosen dalam pelaksanaan tugas pendidikan dan pengajaran; perencanaan pembelajaran; proses pembelajaran; pemberian tugas terstruktur; interaksi dosen dengan mahasiswa; evaluasi hasil belajar; dan penguasaan bahan dan metodologi.

Dosen juga mempunyai kegiatan sebagai tenaga pengajar yang terdiri atas hal-hal sebagai berikut: (1) memperoleh ijazah sampai stratum tertinggi; (2) memberikan kuliah tutorial/menguji; (3) menyelenggarakan kegiatan pendidikan di 
laboratorium, praktik bengkel/ studio, dan praktik lapangan; (4) membimbing seminar mahasiswa; (5) membimbing KKN; (6) membimbing pembuatan laporan, skripsi, tesis, dan disertasi; (7) bertugas dalam panitia ujian akhir; (8) membina kegiatan kemahasiswaan; (9) membimbing mahasiswa sebagai calon tenaga pengajar/ tenaga pengajar dalam rangka studi lanjut; (10) membina tenaga pengajar yang lebih muda; dan (11) /menulis diktat, modul, naskah tutorial, pengembangan studi-modul, dan buku pelajaran perguruan tinggi (Sumardjoko, 2010)

\section{2). Peran Dosen dalam Penelitian}

Penelitian yang berkualitas merupakan syarat dari aspek penelitian, yakni permasalahan dengan latar belakangnya, tujuan yang hendak dicapai, kerangka pemikiran, premis atau hipotesis atau pertanyaan penelitian, metode, hasil serta kesimpulan penelitian. Menurut Nasution (1991:23-25) penelitian dinyatakan berkualitas apabila memiliki syarat sebagai berikut: latar belakang beserta rincian permasalahannya, tujuan dan manfaat penelitian, kerangka pemikiran, hipotesis atau pertanyaan penelitian, paradigm penelitian, prosedur atau metode, kesimpulan hasil penelitian dan rekomendasi berupa saran. Pemikiran tersebut memandang secara keseluruhan aspek sebagai satu kesatuan yang menggambarkan penelitian yang utuh.

Berdasarkan beberapa pendapat di atas maka kualitas kinerja dosen dapat dilihat dari perannya dalam penelitian, baik secara kualitatif maupun kuantitatif, yakni sejauh mana: (1) upaya mendapatkan pengetahuan; (2) penyusunan rencana dan pelaksanaan penelitian; (3) pelaporan penelitian; (4) sumber biaya penelitian; (5) pemanfaatan hasil penelitian; dan (6) banyaknya aktifitas penelitian. Selain itu terkait dengan tugas penelitian, kinerja dosen dapat dilihat dari peran dan aktifitasnya dalam berbagai kegiatan ilmiah, misalnya sebagai pemrasaran, menulis buku yang keasliannya dapat dipertanggungjawabkan atau dapat juga menerjemahkan karya orang lain. Ternasuk peran dosen dalam bidang ini adalah menulis karya ilmiah atau menciptakan karya seni desain; menyajikan karya tulis dalam pertemuan ilmiah atau karya seni / pameran; dan menulis buku ilmiah. 
3). Peran Dosen dalam Pengabdian kepada Masyarakat

Menurut buku Panduan Pelaksanaan Penelitian dan Pengabdian Kepada Masyarakat yang dikeluarkan (DP3M Dikti: 2002), pengabdian masyarakat oleh Perguruan Tinggi (PT) diartikan sebagai pengamalan IPTEKS yang dilakukan oleh Perguruan Tinggi secara melembaga melalui metode ilmiah langsung kepada masyarakat (di luar kampus yang tidak terjangkau oleh progam pendidikan formal) yang membutuhkannya, dalam upaya mensukseskan pembangunan dan mengembangkan manusia pembangunan.

Kegiatan pengabdian kepada masyarakat menjadi bagian yang tidak terpisahkan dari tugas dosen, ditujukan dan diarahkan untuk menunjang pembangunan di barbagai lapisan masyarakat. Berdasarkan fungsi dan sasarannya, tolok ukur kinerja dosen dalam pengabdian kepada masyarakat tidak hanya berkaitan dengan keilmuan, namun berkaitan dengan kelembagaan dan kemasyarakatan, hal ini berarti menyangkut masalah pengadministrasian kegiatan warga kampus di luar kampus.

Secara lebih operasional fungsi pengabdian masyarakat adalah: (1) mengamalkan pengetahuan, teknologi dan seni; (2) membantu masyarakat dalam pembangunan; dan (3) melaksanakan pola pembangunan dan konsepsi pembangunan yang sesuai untuk pembangunan dan pengembangan daerah melalui kerjasama perguruan tinggi dan badan-badan lain. Selanjutnya, tugas dosen dalam pengabdian kepada masyarakat, yaitu: (1) memberi latihan, penyuluhan dan penataran kepada masyarakat; (2) memberikan pelayanan kepada masyarakat atau kegiatan lain yang menunjang pelaksanaan tugas umum pemerintahan dan pembangunan; dan (3) membuat/ menulis karya pengabdian kepada masyarakat termasuk penulisan buku pelajaran SMA ke bawah.

Sebagian faktor penyebab kinerja dosen yang kurang atau belum memuaskan mahasiswa dan pimpinan dapat diprediksi karena adanya kualifikasi akademik yang belum memenuhi syarat minimum dan pengalaman kerja yang masih kurang atau rendah. Kualifikasi akademik adalah ijazah yang dipersyaratkan untuk dimiliki seorang (dosen) sesuai dengan jenis, jenjang dan satuan pendidikan formal di tempat penugasan (Undang-undang Republik Indonesia No 14 Tahun 2005). Selain itu kualifikasi akademik dapat diartikan 
sebagai tingkat pendidikan yang mencerminkan keahlian dan kewenangan seseorang untuk menduduki jabatan tertentu. Kualifikasi akademik pada penelitian ini diartikan sebagai tingkat pendidikan (yang harus dimiliki dosen) minimum berpendidikan magister (S.2) untuk program diploma dan sarjana (S.1) dan pendidikan doctor (S.3) untuk program pascasarjana. Tingkat pendidikan dimaksud diharapkan linier dengan pendidikan sebelumnya (S.1) atau (S.2) yang dimiikinya, ada relevansi dan konsitensi dengan tugas-tugas yang diampu atau diembannya.

Di samping kualifikasi akademik, dosen juga diharapkan memiliki pengalaman kerja yang cukup yang dapat mendukung kinerja dosen secara profesional. Pengalaman kerja adalah pengetahuan atau ketrampilan yang telah diketahui dan dikuasai seseorang sebagai akibat dari perbuatan atau pekerjaan yang telah dilakukan selama beberapa waktu tertenu (Trijoko,1980:82). Menurut Ranupandoyo (1984:71) pengalaman kerja adalah ukuran lama waktu atau masa kerja yang telah ditempuh seseorang, sehingga memahami tugas-tugas suatu pekerjaan dan telah melaksanakan dengan baik. Pengalaman kerja adalah proses pembentukan pengetahuan atau ketrampilan tentang metode suatu pekerjaan karena keterlibatan karyawan tersebut dalam pelaksanaan tugas pekerjaan. (Manulang, 1984:15)

Pengalaman kerja (dalam penelitian ini) diberi makna sebagai kualitas dan kuantitas pengetahuan dan ketrampilan yang diketahui dan dimiliki dosen sebagai akibat dari kerjanya yang menyangkut pendidikan / pengajaran, penelitian, pengabdian kepada masyrakat dan hal-hal lain yang menunjang karier dan profesinya sebagai dosen (baik sebelum maupun sesudah di IKIP PGRI Madiun) yang dipersepsi dan dirasakan sebagai sesuatu yang bermanfaat dalam menjalankan peran dan fungsinya sebagai dosen.

Indikator (pengalaman kerja), meliputi: masa kerja / lamanya bekerja, baik sebelum mapun sesudah jadi dosen di IKIP PGRI Madiun, yang berkaitan dengan jabatan fungsional (dosen), jabatan struktural maupun jabatan-jabatan lain yang berkaitan dengan organisasi profesi) dan yang menunjang karier / profesinya sebagai dosen, dan pengalamannya dibidang pendidikan /pengajaran, penelitian, dan pengabdian kepada masyarakat). 
Karena dosen dianggap lebih tahu tentang dirinya, dapat merasakan dan mempersepsikan dirinya, maka terkait dengan hal-hal sebagaimana dibicarakan di depan, maka diharapkan dosen mampu mengukur dirinya sendiri melalui apa yang disebut dengan evaluasi diri (self assessment).

\section{Metode Penelitian}

Penelitian ini menggunakan jenis pendekatan kuantitatif yang bersifat expost facto, peneliti tidak melakukan exsperiment, tidak perlu melakukan manipulasi dan atau tindakan apapun terhadap variabel yang diteliti. Consuelo (1993) menyebutkan, bahwa: "Penelitian bersifat expost facto dilakukan untuk mengetahui sesuatu setelah kejadian berlangsung, tanpa melakukan tindakan terhadap variabel yang diteliti”.

Adapun paradigma atau model penelitian yang dipakai berdasarkan kerangka berpikir yang dipakai dalam penelitian dapat dilihat pada Gambar 1 .

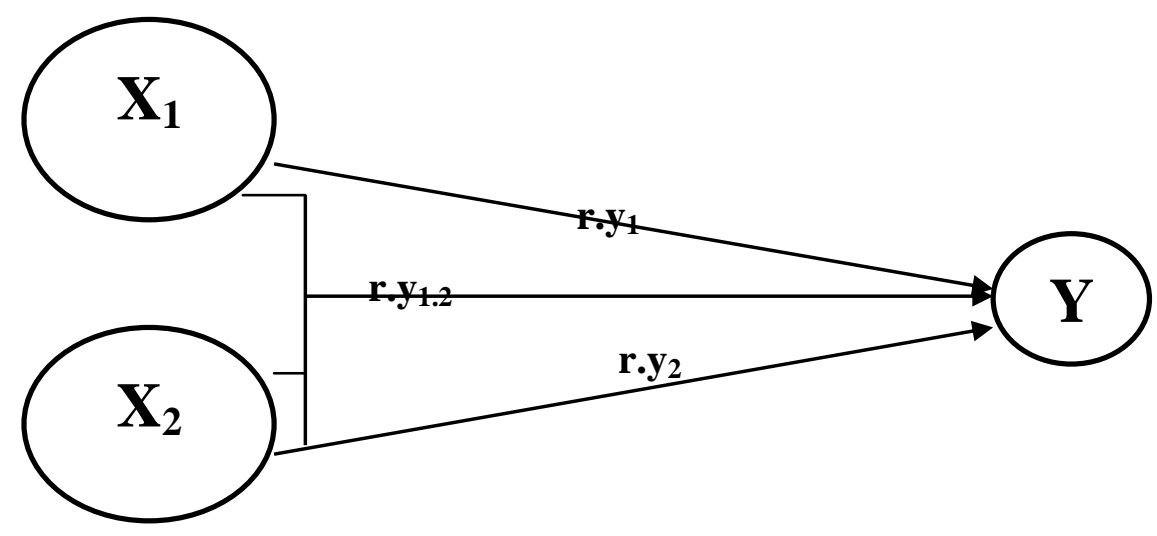

Gambar 1 Paradigma Penelitian

Keterangan: $X_{1}$ adalah variabel kualifikasi akademik; $X_{2}$ adalah pengalaman kerja dan Y adah variabel kinerja dosen.

Populasi penelitian seluruh dosen IKIP PGRI Madiun, sebanyak 155 dosen, dengan jumlah sampel 105, diambil dengan teknik proporsional rondum sampling. Sedangkan teknik pengumpulan data menggunakan teknik angket, bentuknya langsug-tertutup. Angket tersebut lebih menekankan pada sifat evaluasi diri (self assessment), karena peneliti beranggapan bahwa responden lebih tahu tentang dirinya untuk dimintai keterangan (informasi) lewat angket tersebut. 
Jumlah item untuk angket kualifikasi akademik terdiri dari 7 item, pengalaman kerja 30 1tem dan kinerja dosen sebanyak 44 item. Angket sebelum digunakan mengumpulkan data telah diujicobakan ( melalui uji validitas dan reliabilitas) terlebih dahulu dan hasilnya dianalisis dengan memanfaatkan bantuan SPSS 17. Adapun hasilnya, semuanya dinyatakan valid dan reliabel.

Sedangkan untuk analisis data, pada penelitian ini menggunakan analisis statistik dengan regresi ganda (multiple regression). Sebelum data dianalisis perlu adanya uji persyaratan normalitas data, linearitas data, multi kolinearitas data, dan homogenitas data. Uji hipotesis dan uji persyaratan pada penelitian ini (semuanya) memanfaatkan jasa bantuan SPSS 17 dan hasilnya semuanya memenuhi persyaratan untuk uji hipotesis.

\section{Hasil Penelitian}

Berikut dapat disajikan hasil analisis statistik deskreptif (output SPSS 17), lihat tabel 1 berikut.

Tabel 1 Hasil Analsis Statistik Deskriptif Variabel Kualifikasi Akademik,Pengalaman Kerja dan Kinerja Dosen (Output SPSS)

\begin{tabular}{|l|r|r|r|}
\hline & $\begin{array}{r}\text { Kualifikasi } \\
\text { Akademik }\end{array}$ & $\begin{array}{r}\text { Pengalaman } \\
\text { Kerja }\end{array}$ & $\begin{array}{r}\text { Kinerja } \\
\text { Dosen }\end{array}$ \\
\hline N Valid & 105 & 105 & 105 \\
$\quad$ Missing & 0 & 0 & 0 \\
Mean & 19,95 & 61,35 & 129,19 \\
Std. Deviation & 2,975 & 18,959 & 16,417 \\
Range & 15 & 76 & 75 \\
Minimum & 12 & 30 & 89 \\
Maximum & 27 & 106 & 164 \\
Sum & 2095 & 6442 & 13565 \\
\hline
\end{tabular}

Berdasarkan nilai tengah (Mean) disajikan deskripsi data dari masing-masing variabel dalam bentuk prosentase menjadi dua kategori sebagai berikut: 
Tabel 2 Destribusi Frekuensi Kategori Data Kualifikasi Akademik $\left(\mathrm{X}_{1}\right)$ Kinerja Dosen (Y) dan Pengalam Kerja $\left(\mathrm{X}_{2}\right)$ dalam Bentuk Prosentase

\begin{tabular}{|c|c|c|c|c|}
\hline \multirow{2}{*}{ Variabel } & \multicolumn{4}{|c|}{ Frekuensi/ \% } \\
\cline { 2 - 5 } & Baik & Kurang/ Buruk & Jumlah & Keter. \\
\hline $\begin{array}{c}\text { Kualifikasi } \\
\text { Akademik (X })\end{array}$ & $37 \%$ & $63 \%$ & $100 \%$ & \\
\hline $\begin{array}{c}\text { Kinerja Dosen } \\
(\mathrm{Y})\end{array}$ & $55 \%$ & $45 \%$ & $100 \%$ & \\
\hline $\begin{array}{c}\text { Pengalam. Kerja } \\
\left(\mathrm{X}_{2}\right)\end{array}$ & $38 \%$ & $62 \%$ & $100 \%$ & \\
\hline
\end{tabular}

Analisis uji hipotesis dalam penelitian ini menggunakan pendekatan statistik dengan analisis regresi ganda (Multiple Regression) memanfaatkan bantuan SPSS 17. Berdasarkan hasil analisis output SPSS untuk uji hipotesis $\mathrm{X}_{1}$ dan $\mathrm{X}_{2}$ secara bersama sama terhadap $\mathrm{Y}, \mathrm{X}_{1}$ terhadap $\mathrm{Y}$ dan $\mathrm{X}_{2}$ terhadap $\mathrm{Y}$ dapat disajikan sebagai berikut

Pengujian hipotesis 1 pada penelitian ini mengunakan uji $\mathrm{F}$, dengan bantuan SPSS. Melalui output SPSS diperoleh F hitung sebesar 9,539 dengan signifikansi (p) $0,000<0,05$. Hasil selengkapnya dapat dilihat pada tabel 4 Anova. Hal ini berarti hipotesis nol $\left(\mathrm{H}_{0}\right)$ ditolak dan hipotesis kerja $\left(\mathrm{H}_{\mathrm{a}}\right)$ yang berbunyi "Ada pengaruh secara positif dan signifikan kualifakasi akademik $\left(\mathrm{X}_{1}\right)$ dan pengalaman kerja $\left(\mathrm{X}_{2}\right)$ secara bersama-sama pada kinerja dosen $(\mathrm{Y})$ ” di terima. Berdasarkan tabel 3 (Model Summary) diperoleh adjusted $R$ Square sebesar 0,141. Hal ini dapat dimaknai, bahwa kinerja dosen bisa dipengaruhi oleh variabel kualifikasi akademik $\left(\mathrm{X}_{1}\right)$ dan pengalaman kerja $\left(\mathrm{X}_{2}\right)$ secara bersamasama dengan pengaruh sebesar 0,141 atau $14,1 \%$, selebihnya $85,9 \%$ kinerja dosen dipengaruhi oleh variabel lain yang tidak menjadi perhatian pada penelitian ini.

Jika dinyatakan kedalam model persamaan regresi $\mathrm{Y}=91,399+0,188$ $X_{1}+0,322 X_{2}$, yang dapat dimaknai, bahwa setiap kenaikan satu unit skor kualifikasi akademik dan pengalaman kerja secara bersama-sama sebesar 0,188+ 0,322 dikwadratkan hasilnya 0,14 (14\%, dibulatkan) akan diikuti oleh kenaikan satu unit skor kinerja dosen sebesar 0,14 (14\%) pada konstanta 91,399. 
Pengujian hipotesis 2 dan 3 mengunakan uji t, dengan memanfaatkan bantuan SPSS. Adapun hasil uji hipotesis 2 melalui uji t, diperoleh $\mathrm{t}$ hitung sebesar 2,042 dengan signifikansinya (p) 0,044 $<0,05$. Hal ini membuktikan bahwa hipotesis nol (Ho) ditolak. Penolakan hipotesis nol berarti penerimaan hipotesis kerja (Ha) yang berbunyi "Ada pengaruh secara positif dan signifikan kualifikasi akademik pada kinerja dosen". Hasil selengkapnya dapat dilihat pada tabel 5 Coeficient). Jika dinyatakan dalam model persamaan regresi $\mathrm{Y}=91,399+$ $0,188 \mathrm{X}_{1}$, yang dapat dimaknai, bahwa setiap kenaikan kualifikasi akademik $\left(\mathrm{X}_{1}\right)$ satu poin sebesar 0,188 (3,54\%) maka akan diikuti kenaikan kinerja dosen (Y) sebesar 0,188 atau 3,54\% pada konstanta 91,399. Hasil selengkapnya dapat dilihat pada tabel 5 Coefficients. Sedangkan hasil uji hipotesis 3 melalui uji t, diperoleh $t$ hitung sebesar 3,504 dengan signifikansinya (p) 0,001<0,05. Hal ini membuktikan bahwa hipotesis nol (Ho) ditolak, dengan demikian hipotesis kerja (Ha) yang berbunyi "Ada pengaruh secara positif dan signifikan pengalaman kerja pada kinerja dosen ", diterima. Hasil selengkapnya lihat pada tabel 5 Coefficients. Jika dinyatakan dalam model persamaan regresi $\mathrm{Y}=91,399+0,322 \mathrm{X}_{2}$, yang dapat dimaknai, bahwa setiap kenaikan pengalaman kerja $\left(\mathrm{X}_{2}\right)$ satu poin sebesar 0,322 (10,36\%), maka akan diikuti kenaikan kinerja dosen (Y) sebesar 0,322 $(10,36 \%)$ pada konstanta 91,399 .

Tabel 3 Model Summary (Output SPSS)

Model Summary

\begin{tabular}{|l|r|r|r|r|}
\hline Model & $\mathrm{R}$ & R Square & $\begin{array}{c}\text { Adjusted } \\
\text { R Square }\end{array}$ & $\begin{array}{c}\text { Std. Error of } \\
\text { the Estimate }\end{array}$ \\
\hline 1 &, $397^{\mathrm{a}}$ &, 158 &, 141 & 15,215 \\
\hline
\end{tabular}

a. Predictors: (Constant), X2, X1

Tabel 4 Anova (Output SPSS)

ANOVA $^{\text {b }}$

\begin{tabular}{|ll|r|r|r|r|r|}
\hline Model & & \multicolumn{1}{|c|}{$\begin{array}{c}\text { Sum of } \\
\text { Squares }\end{array}$} & \multicolumn{1}{c|}{ df } & Mean Square & \multicolumn{1}{l|}{ F } & Sig. \\
\hline 1 & Regression & 4416,398 & 2 & 2208,199 & 9,539 &, $000^{\mathrm{a}}$ \\
& Residual & 23611,792 & 102 & 231,488 & & \\
& Total & 28028,190 & 104 & & & \\
\hline
\end{tabular}

a. Predictors: (Constant), X2, X1

b. Dependent Variable: $Y$ 
Tabel 5 Coefficients (Output SPSS)

Coefficients ${ }^{a}$

\begin{tabular}{|c|c|c|c|c|c|c|}
\hline \multirow{2}{*}{\multicolumn{2}{|c|}{ Model }} & \multicolumn{2}{|c|}{$\begin{array}{c}\text { Unstandardized } \\
\text { Coefficients }\end{array}$} & \multirow{2}{*}{$\begin{array}{c}\begin{array}{c}\text { Standardized } \\
\text { Coefficients }\end{array} \\
\text { Beta } \\
\end{array}$} & \multirow[b]{2}{*}{$\mathrm{t}$} & \multirow[b]{2}{*}{ Sig. } \\
\hline & & $\mathrm{B}$ & Std. Error & & & \\
\hline & (Constant) & 91,399 & 10,651 & & 8,581 &, 000 \\
\hline & X1 & 1,036 &, 507 & , 188 & 2,042 &, 044 \\
\hline & $X 2$ &, 279 & ,080 & ,322 & 3,504 &, 001 \\
\hline
\end{tabular}

a. Dependent Variable: $Y$

\section{Pembahasan}

Berdasarkan temuan dan analisis data sebagaimana disajikan sebelumnya diperoleh temuan-temuan yang sekaligus merupakan jawaban terhadap masalah yang dihadapi peneliti. Temuan dan jawaban tersebut secara umum membenarkan bahwa kualifikasi akademik dan pengalaman kerja mempunyai pengaruh (kontribusi) secara positif dan signifikan pada kinerja dosen IKIP PGRI Madiun. Namun temuan dan jawaban ini masih perlu dibahas lebih lanjut sebagai berikut.

Hasil analisis deskriptif antara variabel kinerja dosen(Y) dan variabel kualifikasi akademik (X1), keduanya menunjukan perbandingan terbalik. Karena frekuensi skor kualifikasi akademik terbesar (63\%) yang berada dibawah rata-rata (menunjukkan kategori kurang) tidak diikuti oleh frekuensi terbanyak skor kinerja dosen (dalam kategori kurang) yang berada di bawah rata-rata, melainkan justru ditemukan frekuensi berbanding terbalik. $\mathrm{FKbrX}_{1}>\mathrm{FKbrY}=63 \%>45 \%=$ selisih $18 \%$ dan FKarX $_{1}<$ FKarY $=37 \%<55 \%=$ selisih $18 \%$. Lebih jelasnya dapat dilihat pada tabel 6 berikut.

Tabel 6. Frekuensi Kategorial Hasil Analisis Deskriptif Perbandingan antara Variabel $\mathrm{X}_{1}$ dengan Y (Berdasarkan Skor Rata-Rata)

\begin{tabular}{|c|c|c|c|c|}
\hline \multirow{2}{*}{ Variabel } & \multicolumn{3}{|c|}{ Frekuensi Kategori /Prosentase (\%) } \\
\cline { 2 - 5 } & $\begin{array}{c}\text { Atas Rata-Rata } \\
\text { (Baik) }\end{array}$ & $\begin{array}{c}\text { Bawah Rata-Rata } \\
\text { (Kurang) }\end{array}$ & $\begin{array}{c}\text { Jumlah } \\
\text { Selisih }\end{array}$ & \\
\hline Kual.Akdmk & $37 \%$ & $63 \%$ & $26 \%$ & - \\
\hline Kinerja Dosen & $55 \%$ & $45 \%$ & $10 \%$ & - \\
\hline Jumlah /Selisih & $18 \%$ & $18 \%$ & $36 \%$ & - \\
\hline
\end{tabular}


Berdasarkan tabel 6. tersebut sebanyak $63 \%$ dosen tergolong memliki kualifikasi akademik kurang (kurang memenuhi syarat minimum), namun secara empiris dari sebagian mereka yang tergolong kualifikasinya rendah ternyata mampu menunjukkan kinerja yang baik (sebanyak 18\%). Sedangkan sisanya 8\% dari mereka (dari 26\%) yang tergolong kualifikasinya rendah secara empiris memang betul-betul kurang mampu berkinerja dengan baik. Jadi secara diskkriptif empiris dapat dibuktikan bahwa tidak semua dosen yang kualifikasi akademiknya kurang (belum memenuhi syarat minimum) kinerjanya pasti jelek atau kurang baik. Hal ini dikarenakan faktor lain juga turut mempengaruhi kinerja dosen. Seperti pengalaman kerja, motifasi kerja atau motivasi berprestasi, komitmen kerja, kompetensi dosen, iklim organisasi, kepemimpinan, sarana dan prasarana, dan sebagainya.

Meskipun demikian berdasarkan temuan (hasil uji hipotesis) secara idividual membuktikan bahwa kualifikasi akademik $\left(\mathrm{X}_{1}\right)$ berpengaruh secara positif dan signifikan pada kinerja dosen, walaupun sumbangan efektif (kontribusinya) hanya sebesar 0,188 atau $3,54 \%$. Hal ini membuktikan bahwa semakin baik /tinggi kualifikasi akademik dosen akan semakin baik atau semakin tinggi pula kinerja dosen tersebut. Semakin kulifikasi akademik dosen memenuhi syarat minimum berpendidikan magister (S.2), linear, selalu konsisten dan relevan dengn bidang tugas yang diemban atau diampunya dosen semakin baik atau semakin mampu bekerja secara maksimal dan profesional. Temuan ini sejalan dengan teori yang mengatakan bahwa semakin tinggi tingkat pendidikan seseorang akan semakin tinggi atau semakin baik kinerjanya. Dengan sendirinya hasil penelitian ini membenarkan (mendukung) apa yang diamanat oleh Undang-undang Republik Indonesia No 14 tahn 2005, tentang guru dan dosen, bahwa dosen harus memiliki kualifikasi akademik minimum berpendidikan magister (S.2) untuk program pendidikan diploma atau sarjana, dan doktor (S.3) untuk program pendidikan pascasarjana. Temuan ini juga sesuai dengan kerangka berpikir dan hipotesis yang diajukan bahwa kualifikasi akademik perpengaruh pada kinerja dosen. Selaian itu juga sejalan dengan temuan Kusdaryani (2007) bahwa tingkat pendidkan 
(kualifikasi akademik) berpengaruh secara positif dan signifikan pada kinerja guru, dengan pengaruh langsung sebesar $0,147(14,7 \%)$.

Hasil analisis deskriptif antara variabel kinerja dosen dan variabel pengalaman kerja tersebut juga ditemukan adanya perbandingan terbalik. Frekuensi skor pengalaman kerja $62 \%$ (terbanyak) dalam kategori kurang yang tidak diikuti oleh frekuensi terbanyak kinerja dosen dalam kategori yang sama (kurang), melainkan justru ditemukan sebaliknya (berbanding terbalik). $\mathrm{FKbrX}_{2}>\mathrm{FKbrY}=62 \%>$ $45 \%=$ selisih $17 \%$ dan $\mathrm{FKarX}_{2}<\mathrm{FKarY}=38 \%<55 \%=$ selisih $17 \%$. Lebih jelasnya dapat dilihat pada tabel 7 berikut.

Tabel 7 Frekuensi Kategorial Hasil Analisis Deskriptif antara Variabel $\mathrm{X}_{2}$ dengan Y (Berdasarkan Skor Rata-Rata)

\begin{tabular}{|c|c|c|c|c|}
\hline \multirow{2}{*}{ Variabel } & \multicolumn{4}{|c|}{ Frekuensi Kategori /Prosentase (\%) } \\
\cline { 2 - 5 } & $\begin{array}{c}\text { Atas Rata-Rata } \\
\text { (Baik) }\end{array}$ & $\begin{array}{c}\text { Bawah Rata-Rata } \\
\text { (Kurang) }\end{array}$ & $\begin{array}{l}\text { Jumlah / } \\
\text { Selisihh }\end{array}$ & $24 \%$ \\
\hline Pengalam. Kerja & $38 \%$ & $62 \%$ & $10 \%$ & \\
\hline Kinerja Dosen & $55 \%$ & $45 \%$ & $34 \%$ & \\
\hline Jumlah / Selisih & $17 \%$ & $17 \%$ & $24 \%$ \\
\hline
\end{tabular}

Meskipun demikian berdasarkan temuan (hasil uji hipotesis) secara individual membuktikan bahwa pengalaman kerja $\left(\mathrm{X}_{2}\right)$ berpengaruh secara positif dan signifikan pada kinerja dosen, walaupun sumbangan efektif (kontribusinya) hanya sebesar 0,322 atau $10,36 \%$. Hal ini berarti semakin baik /tinggi pengalaman kerja dosen akan semakin baik atau semakin tinggi pula kinerja dosen. Sebaliknya semakin jelek pengalaman kerja dosen akan semakin jelek pula kinerja dosen.

Temuan ini sesuai dengan teori bahwa kenerja dosen dipengaruhi oleh banyak faktor, termasuk di dalamnya adalah faktor pengalaman kerja. Semakin banyak pengalaman kerja seseorang akan semakin trampil dalam melaksanakan tugas dan kewajibannya. Hasil penelitian ini juga sejalan dengan kerangka berpikir dan hipotesis yang diajukan bahwa penngalaman kerja berpengaruh pada kinerja dosen. Temuan ini juga sejalan dengan temuan Kusdaryani (2007) bahwa pengalaman kerja berpengaruh secara positif dan signifikan pada kinerja guru. Besarnya pengaruh langsung 0,663 (66,3\%). 
Berdasarkan hasil temuan melalui analisis regresi ganda diperoleh $\mathrm{F}_{\mathrm{h}}$ sebesar 9,539 dengan signifikansinya sebesar 0,00 $<0,05$. Hal ini membuktikan bahwa $\mathrm{H}_{0}$ ditolak dan $\mathrm{H}_{\mathrm{a}}$ diterima yang berarti secara empiris terbukti bahwa kualifikasi akademik $\left(\mathrm{X}_{1}\right)$ dan pengalaman kerja $\left(\mathrm{X}_{2}\right)$ positif dan signifikan berpengaruh secara bersama-sama pada kinerja dosen (Y). Jika dilihat sumbangan efektif atau kontribusinya secara bersama-sama pada output SPSS diperoleh Adjusted $R$ Scquare sebasar 0,141 atau 14,1\% (output SPSS, tabel model summary), ini membuktikan bahwa terdapat pengaruh atau kontribusi secara bersama-sama dari variabel kualifikasi akademik dan pengalaman kerja pada kinerja dosen sebesar 0,141 atau $14,1 \%$. Selebihnya $85,9 \%$ kinerja dosen dipengaruhi oleh variabel lain yang dalam penelitian ini tidak diteliti atau tidak menjadi pusat perhatian. Hal ini berarti membenarkan juga, bahwa banyak faktor yang turut mempengaruhi kinerja dosen. Seperti motivasi kerja atau motivasi berprestasi, komitmen dosen, sarana dan prasarana, kompensasi, kompetensi, kepemimpinan, iklim kerja dan budaya organisasi dan lain sebagainya.

Jika temuan empiris ini dilihat dari model persamaan regresi $\mathrm{Y}=91,399+$ $0,188+0322$, berarti bahwa setiap kenaikan satu unit skor kualifikasi akademik dan pengalaman kerja sebesar $(0,188+0,322)^{2}=3,54 \%+10,36 \%$ atau $14 \%$ (dibulatkan) akan diikuti kenaikan kinerja dosen sebesar 3,54\% +10,36\% atau 14\%. Temuan empiris ini juga membuktikan bahwa pengalaman kerja memiliki sumbangan (kontribusi) lebih besar jika dibandingkan dengan sumbangan (kontribusi) kualifikasi akademik dosen, yaitu 10,36\% > 3,54\%.

Temuan ini sesuai dengan teori yang mengatakan bahwa kinerja (seseoran) dipengaruhi banyak faktor, baik faktor internal maupun faktor eksternal. Faktor internal seperti: kemauan dan kemampuan, sikap, dan kecakapan, motivasi berprestasi, dan komitmen kerja, persepsi seseorang terhadap pekerjaan atau terhadap organisasi, dan lain sebagainya. Kemampuan dan kecakapan seseorang untuk bekerja juga dipengaruhi oleh pendidikan (tingkat pendidikan) dan latihan (pengalaman kerja). Faktor eksternal seperti, kepemimpinan, dukungan teman sejawat, iklim organisasi, budaya organisasi, gaji atau imbalan kerja, dan lain sebagainya. Faktor-faktor tersebut tidak bekerja secara terpisah, meainkan salig kerja sama dan bisa saling pengaruh-mempengaruhi, baik secara terpisah maupun 
secara bersama-sama. Selain itu hasil penelitian ini juga sejalan dengan temuan Kusdaryani (2007) yang mengatakan bahwa "Ada pengaruh positif dan signifikan tingkat pendidikan (kualifikasi akademik) dan pengalaman kerja terhadap kinerja guru SMP Kota Solotiga". Sumbangan efektif (pengaruh langsung) tingkat pendidikan (kualifikasi akademik) dan pengalaman kerja sebesar 0,147 < 0,663. Jadi pengalaman kerja mempunyai smbangan lebih besar, jika dibandinkan dengan tingkat pendidikan (kualifikasi akademik), yaitu sebesar hanya sebesar yaitu 0,663 atau $66,3 \%>0,147$ atau $14,7 \%$.

Jadi secara empiris betul-betul terbukti, bahwa kualifikasi akademik dan pengalaman kerja secara bersama-sama berpengaruh (memiliki kontribusi) positif dan signifikan pada kinerja dosen, walaupun besar pengaruh dari keduanya tidak sama dan hanya kecil, jika dibandingkan dengan faktor lain diluar variabel penelitian yang tiak menjadi pusat perhatian dalam penelitian ini.

\section{Kesimpulan dan Saran}

Berdasarkan temuan empiris (hasil penelitian) dan pembahasan dapat disimpulkan, bahwa terdapat pengaruh (kontribusi) secara positif dan signifikan baik secara individual maupun secara bersama-sama kualifikasi akademik dan pengalaman kerja pada kinerja dosen IKIP PGRI Madiun.

Berdasarkan hasil penelitian yang telah dilakukan, dapat diberikan saran sebagai berikut: bagi dosen hendaknya selalu meningkatkan kinerjanya seoptimal mungkin, terutama terkait dengan antara lain melalui peningkatan kualifikasi akademik (S-2 bagi yang belum dan S-3 bagi yang sudah S-2) dan tidak kalah pentingnya juga melalui peningkatan pengalaman kerja.

Bagi Dikti dan Lembaga Pendidikan Tinggi (IKIP PGRI Madiun) untuk meningkatkan kualitas SDM (tenaga dosen), khususnya dalam rekrutmen perlu mempertimbangkan kualifikasi akademik dan pengalaman kerja calon dosen. Selain itu agar kinerja dosen semakin berkualitas, maka dengan kualifikasi akademik dan pengalaman kerja yang dimiliki dosen tersebut, perlu didukung juga berbagai fasilitas yang diperlukan.

Bagi peneliti berikutnya. Untuk melengkapi hasil penelitian ini (tentang kinerja dosen), sebaiknya diteliti atau dikaji lebih mendalam mengenai variabel 
lain, diluar kualifikasi akademik dan pengalaman kerja yang menjadi pusat perhatian pada penelitian ini.

\section{Daftar Pustaka}

Depdiknas. 2003. Panduan Pelaksanaan Penelitian dan Pengabdian kepada Masyarakat. Edisi VI. Jakarta:Direktorat Pembinaan Penelitian dan Pengabdian kepada Masyarakat, Direktorat Jendral Penddikan Tinggi.

Fatah. 2003. Landasan Manajemen Pendidikan. Bandung: Remaja Rosdakarya.

Ghozali. 2001. Aplikasi Analisis Multivariate dengan Program SPSS. Semarang: Badan Penerbit Universitas Diponegoro.

Gibson, D. 1992. Personnel Management. Terjemahan Agus Dharma. Jakarta : Erlangga.

Kusdaryani. 2007. Pengaruh Tingkat Pendidikan dan Pengalaman Kerja terhadap Kinerja Guru dan Prestasi Belajar Siswa. Tesis tidak diterbitkan. Semarang: PPs. UNNES

Mangkunegara. 2005. Manajemen Sumber daya Manusia Perusahaan. Bandung : Remaja Rosdakarya.

Nasution. 1991. Metode Research, Peneliyian Ilmiah, Thesis. Bandung: Jemmars

Parji . 2010. IKIP PGRI Madiun Mendapat Anugerah Kampus Unggulan (AKU). Jawa Pos, 24 September. 2010 : 43.

Riduwan \& Kuncoro,E.A., 2008. Cara Menggunakan dan Memaknai Analisis Jalur (Part Analysiss). Bandung: Alfabeta.

Robbins, S.P. 2006. Perilaku Organisasi. New Jersey: Person Education,Inc.

Sedarmayanti. 2001. Sumber Daya Manusia dan Produktivitas Kerja. Bandung : Mandor Maju.

Sumardjoko, B. 2010. Peran Dosen dalam Penjaminan Mutu di Perguruan Tinggi (Disertasi). Semarang: Pascasarjana Unnes.

Undang-Undang Republik Indonesia No 14 Tahun 2005 Tentang Guru dan Dosen. Bandung : Citra Umbara. 